\title{
Thermodynamic Modeling of Uranium (VI) Reductive Immobilization in Groundwater of NPCC Sludge Storages (Novosibirsk, Russia)
}

\author{
Olga L. Gaskova',2, A. E. Boguslavsky ${ }^{1,2}$, A. V. Safonov ${ }^{3}$ \\ ${ }^{1}$ Sobolev Institute of Geology and Mineralogy SB RAS, Novosibirsk, Russia \\ ${ }^{2}$ Novosibirsk State University, Novosibirsk, Russia \\ ${ }^{3}$ Frumkin Institute of Physical Chemistry and Electrochemistry, Russian Academy of Sciences (IPCE RAS), Moscow, Russia \\ Email: Gaskova@igm.nsc.ru, Boguslavsky@igm.nsc.ru, alexeysafonof@gmail.com
}

How to cite this paper: Gaskova, O. L., Boguslavsky, A. E., \& Safonov, A. V. (2018). Thermodynamic Modeling of Uranium (VI) Reductive Immobilization in Groundwater of NPCC Sludge Storages (Novosibirsk, Russia). Journal of Geoscience and Environment Protection, 6, 181-189.

https://doi.org/10.4236/gep.2018.611014

Received: June 29, 2018

Accepted: November 27, 2018

Published: November 30, 2018

\begin{abstract}
The Biochemical Reduction Of Both Nitrate And Sulfate In U-Containing Aquifers Of The Novosibirsk Plant Of Chemical Concentrates (NPCC) Was Investigated Experimentally And Thermodynamically. It Was Observed That Decrease In Eh Up To -397 Mv Has A Distinct Effect On The Denitrification And Uranium Precipitation As $\mathrm{UO}_{2(\mathrm{~s})}$. Nitrate Was Denitrified With A Temporary Accumulation Of The Intermediate Nitrite On The Day $4^{\text {th }}$. According To The X-Ray Fluorescence Analysis And Thermodynamic Calculations, More Than Half Of The Uranium Is Deposited In The First Stage As $\mathrm{UO}_{2+\mathrm{X}}$ oxides, And The Rest, Together With The Sulfides In The Reducing Environment. Findings Suggest That Accurately Thermodynamic Predicting Of Groundwater $\mathrm{NO}_{3}^{-}$And $\mathrm{SO}_{4}^{2-}$ Fate Is Primarily Limited By Failing To Account For A Kinetic Of Redox Fluctuations In The Experiment: 1) Measured Eh $+190 \mathrm{Mv}$ Is Low Despite The High Amount Of Nitrates (1124 Mg/L), But $\mathrm{NH}_{4}^{+}$Predominates In Solution According To Calculations, 2) Sulfate Reduction Lagged Behind Nitrate Reduction By Approximately 50 Days Unlike Model Simulation.
\end{abstract}

\section{Keywords}

Uranium Wastes, Bacterialreduction, Nitrogen, Sulfur, Thermodynamic Model

\section{Introduction}

In view of the chemical complexity of the low-level wastes and the variation in 
the physical-chemical conditions in time and to depth under the repositories, the thermodynamic simulation of the processes occurring during the storage of manufactured radioactive wastes is a non-trivial task (Gaskova et al., 2015). Themodel scientific ability to accurately describe uranium speciation in sludge and subsurface sediments is not comprehensive. For sediments, aside from incomplete identification of the mineralogical components and their key thermodynamic properties, amorphous and poorly crystallized substances are common because of radio emission. Besides the potential role of the above conditions, contaminant mobility within repositories can be altered by the presence of microorganisms (Keith-Roach et al., 2002). A number of safety assessments already incorporate microbial processes into the predictive modelling of repository conditions (Hallbeck et al., 2012). At the same time, thermodynamic model can provide a general direction for ground water purification methods and a geoecological assessment of the repositories environment in after years.

The purpose of this study is to develop a thermodynamic model of the immobilization process of contaminants during the biogeochemical redox processes with the characteristics of the $\mathrm{U}, \mathrm{N}, \mathrm{S}$, and Fe species in experimental solutions and solid phases.

\section{Materials and Methods}

\subsection{Study Object}

The low-level waste repository of the Novosibirsk Plant of Chemical Concentrates (NPCC) is in operation since 1954 and is located at a distance of several kilometers from the Novosibirsk city center. It consists of two series-arranged sludge repositories in the thalweg of a bogged gully. The first of them has been decommissioned and dried with the territory remediation, and the second one is prepared for decommissioning in 2019. Liquid nitric and sulfuric acid wastes from uranium enrichment were discharged into sludge repositories after preliminary neutralization with milk of lime. The liquid phase of the slurry drained through the bottom and sides of the repositories. Knowledge about the spatial distribution of in situ nitrate- and sulfate contaminated aquifers is crucial to predict the groundwater quality. The fate of trace oxyanions is dependent on the ability of main pollutants to change the redox state in groundwater systems and to change the sorption capacity of the underlying sediments (Boguslavskii et al., 2016). Groundwater was sampled from location not far from the sludge repositories from a depth of 8 meters within the Middle Quaternary sediments of the Krasnodubrovskaya suite, consisting of interbedded sands, sandy loams, and loams. The prevalent minerals are quartz and feldspars with rare calcite grains.

\subsection{Previous Experiment}

This study is the second part of a combined approach 1) to quantify experimentally a biochemical reduction of elements in contaminated aquifers of the NPCC (Safonov et al., 2019), 2) to simulate thermodynamically main controlling factors 
and derive predictive model of the water treatment. In previous part, groundwater passed through a $0.45 \mathrm{~mm}$ filter was collected for ions, carbonate, and nitrate and sulfate analysis. Conductivity, $\mathrm{T}, \mathrm{pH}$, redox potential (Eh) and dissolved oxygen (DO) were measured in-situ using a multi-parameter Hanna Instruments.

The nutrient serum $(250 \mathrm{ml} / \mathrm{L})$ and $4 \mathrm{mg} / \mathrm{L}$ of uranium as $\mathrm{UO}_{2}\left(\mathrm{NO}_{3}\right)_{2}$ were added to the reservoir waters containing biota and the $10 \mathrm{ml}$ bottles were immediately sealed with grey butyl rubber septa and aluminium crimp caps. This multi-contaminant mixture was analyzed four times by ICP-MS in 4, 13, 28, 64 days. Serum contains, mg/L-78 P, $130 \mathrm{~K}, 42 \mathrm{Na}, 8 \mathrm{Mg}, 60 \mathrm{Ca}, 0.06 \mathrm{Fe}$ and $67 \mathrm{Cl}$, vitamins. The nutrient serum has been used for biostimulation aimed at immobilizing uranium. We suppose microbial denitrification dominates nitrate losses from the NPCC aquifers.

\subsection{Geochemical Modeling}

Thermodynamic modeling was performed with the "HCh" (ver. 4.4) computer code at $25^{\circ} \mathrm{C}$ and 1 bar total pressure using a free energy minimization algorithm and the UNITHERM database (Shvarov, et al., 2008). We modeled the heterophase 17-component system H-O-Ca-Na-Mg-K-Cl-Si-Al-Fe-S-N-C-P-U-Cu-Zn. Dissolved and adsorbed U-species, as well as $U$ solid phases, were incorporated. Biogeochemical modelling was designed to identify key reactive processes controlling the behaviour of $\mathrm{U}, \mathrm{N}, \mathrm{S}$ and Feduring the experiment, by reproducing acertain bacillus as $-\mathrm{CH}_{2} \mathrm{O}$ (Gaskova et al., 2017) (Stucker et al., 2014). One would expect the next reactions:

$$
\begin{gathered}
2.5\left[-\mathrm{CH}_{2} \mathrm{O}\right]+2 \mathrm{NO}_{3}^{-}+2 \mathrm{H}^{+}=2.5 \mathrm{CO}_{2 \text { (gas) }}+\mathrm{N}_{2 \text { (gas) }}+3.5 \mathrm{H}_{2} \mathrm{O} \\
0.25\left[-\mathrm{CH}_{2} \mathrm{O}\right]+\mathrm{Fe}(\mathrm{OOH})_{\text {coll. }}+2 \mathrm{H}^{+}=0.25 \mathrm{CO}_{2}+1.75 \mathrm{H}_{2} \mathrm{O}+\mathrm{Fe}^{2+} \\
{\left[-\mathrm{CH}_{2} \mathrm{O}\right]+0.5 \mathrm{SO}_{4}^{2-}+0.5 \mathrm{H}^{+}=0.5 \mathrm{HS}^{-}+\mathrm{CO}_{2}+\mathrm{H}_{2} \mathrm{O}} \\
0.5\left[-\mathrm{CH}_{2} \mathrm{O}\right]+\mathrm{UO}_{2}^{2+}=\mathrm{UO}_{2(\mathrm{~s})}+0.5 \mathrm{CO}_{2}+2 \mathrm{H}^{+} \\
\mathrm{Fe}^{2+}+2 \mathrm{HS}^{-}+0.5 \mathrm{O}_{2}=\mathrm{FeS}_{2}+\mathrm{H}_{2} \mathrm{O}
\end{gathered}
$$

The role of the reaction (1) is to convert nitrate (an important component of bacterial nutrition) to biologically inert molecular nitrogen. Unfortunately, in the experiment we fixed only the intermediate reaction (6). The reaction (1) is expected to proceed on the basis of a sharp drop in $\mathrm{NO}_{3}^{-}$concentrations up to $10 \mathrm{mg} / \mathrm{L}$ on the $13^{\text {th }}$ experimental day.

$$
0.5\left[-\mathrm{CH}_{2} \mathrm{O}\right]+\mathrm{NO}_{3}^{-}=0.5 \mathrm{CO}_{2(\text { gas })}+\mathrm{NO}_{2}^{-}+0.5 \mathrm{H}_{2} \mathrm{O}
$$

The processes $(1,6)$ are entirely due to the activity of denitrifying bacteria, which have the ability to reduce nitrate through nitrite to gaseous nitrous oxide and nitrogen. The molar amount of $-\mathrm{CH}_{2} \mathrm{O}$ was selected not in accordance with the stoichiometry of reactions $(1-6)$, but to reproduce most accurately the solution Eh measured in the experiment. For example, it was necessary to introduce 
$0.026 \mathrm{~mol}$ of $-\mathrm{CH}_{2} \mathrm{O}$ per liter of solution containing the amount of $\mathrm{NO}_{3}^{-}$and $\mathrm{SO}_{4}^{2-}$ to fit $+190 \mathrm{Eh}, \mathrm{mV}$.

The Saturation Index (SI) is a method of determining whether water will deposit minerals or maintain their in solution (corrosive water). The ideal result is to have alg SI $=0$, balanced water is between \pm 0.3 supersaturated is $>0.3$.

\section{Results}

Total aqueous $\mathrm{NO}_{3}^{-}$(squares), $\mathrm{NO}_{2}^{-}$(diamonds), $\mathrm{SO}_{4}^{2-}$ (crosses) concentrations and $\mathrm{Eh}, \mathrm{mV}$ (triangles) during the biostimulation experiment are shown in Figure 1. The initial solution contain, mg/L-1124 $\mathrm{NO}_{3}^{-}, 1769 \mathrm{SO}_{4}^{2-}, 161 \mathrm{HCO}_{3}^{-}$, $217 \mathrm{Na}, 577 \mathrm{Ca}, 10.7 \mathrm{Fe}$ and $590 \mathrm{Cl}$ and minor elements at $\mathrm{pH}$ 6.8, Eh $+190 \mathrm{mV}$.

As listed in Table 1, initial solution is slightly supersaturated with respect to goethite, cuprite and kaolinite and is in equilibrium with quartz, mixture of uranium oxides, calcite and gypsum. It is known that $\mathrm{NO}_{3}^{-}$and $\mathrm{NO}_{2}^{-}$reduction by bacteria is inhibited in the presence of goethite (Coby et al., 2005). The hypothetical mechanism offered to explain this finding involved the formation of a Fe(III) (hydr)oxide coating on the cell via the surface-catalyzed abiotic reaction between $\mathrm{Fe}^{2+}$ and $\mathrm{NO}_{2}^{-}$. This coating could inhibit reduction of $\mathrm{NO}_{x}^{-}$by physically blocking transport into the cell.

Table 1. Precipitated solid phases from model initial solution, their quantity and Saturation Indices (SI) of minerals in equilibrium with solution.

\begin{tabular}{ccccc}
\hline Mineral & Quantity, mol/L & Quantity, \% & Mineral & $\operatorname{lg~SI}$ \\
\hline Cuprite $\mathrm{Cu}_{2} \mathrm{O}$ & $2.51 \mathrm{E}-05$ & $15.5 \%$ & Quartz & -0.10 \\
Goethite & $1.92 \mathrm{E}-04$ & $73.3 \%$ & $\mathrm{U}_{3} \mathrm{O}_{8}$ & -0.16 \\
Kaolinite & $7.97 \mathrm{E}-06$ & $8.9 \%$ & Calcite & -0.25 \\
& & Gypsum & -0.16 & \\
\hline
\end{tabular}

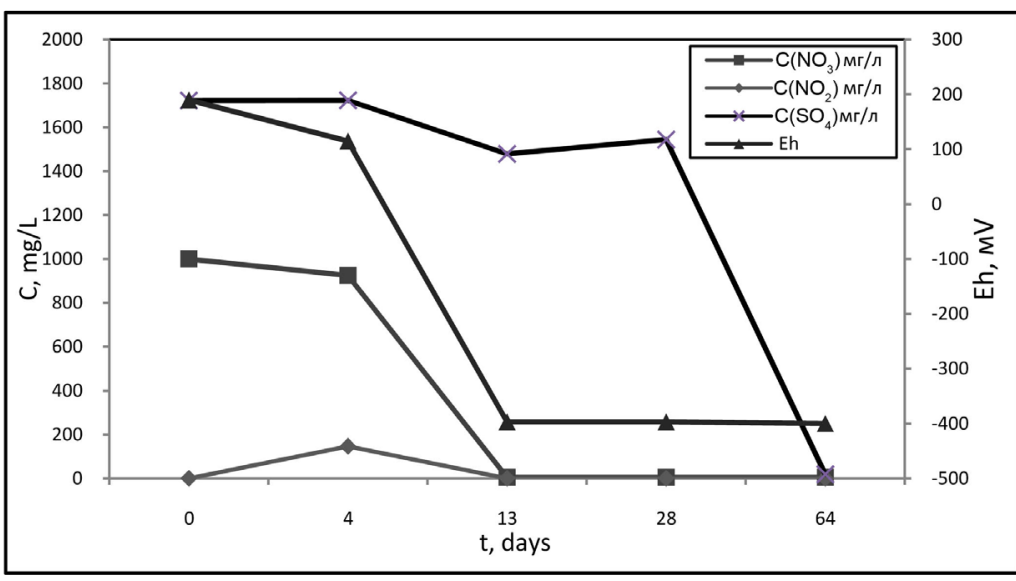

(a)

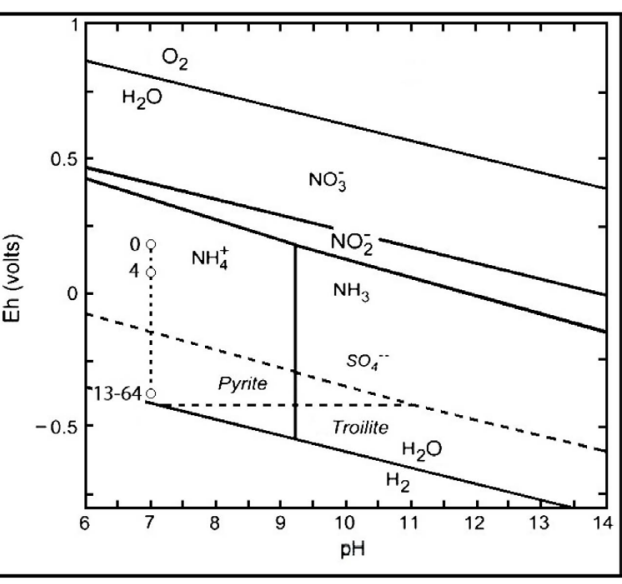

(b)

Figure 1. Dynamics of experimental changes in the values the concentration of nitrates, nitrites and sulfates and of Eh in the sample after the addition of the nutrient serum. The left axis corresponds to the concentrations, and the right axis applies to Eh, $\mathrm{mV}$ (A). Sketch of Eh-pH dyagramm of the N-O-Fe-S-water system, where elements activities are near $0.001 \mathrm{M}$. 
The neutral point of water at temperature $25^{\circ}$ is $\mathrm{pH} 7$ and $\mathrm{Eh}+400 \mathrm{mV}$, so measured in situ $\mathrm{Eh}+190 \mathrm{mV}$ is low despite the high amount of nitrates (1124 $\mathrm{mg} / \mathrm{L})$. According to calculations, $\mathrm{NH}_{4}^{+}$predominates in solution, iron species are $\mathrm{Fe}(\mathrm{OH})_{3(\mathrm{aq})}$ mainly and $25 \%$ of $\left(\mathrm{Fe}^{2+}\right.$ and $\left.\mathrm{FeSO}_{4(\mathrm{aq})}\right)$, and carbonate complexes of $\mathrm{U}(\mathrm{VI})$ predominate, sulfur is present as $\mathrm{SO}_{4}^{2-}$. This means slow kinetic of electrochemical interactions in natural aquifers. Taking into account these facts, we have to agree with (Nordstrom et al., 2000) that "redox disequilibria is the rule".

As nitrogen and phosphorous are the two most common limiting nutrients in natural ecosystems, on the $4^{\text {th }}$ days after the serum adding we have fixed $\mathrm{Eh}+115$ $\mathrm{mV}$ (Figure 1, point 4 days). The main result was the appearance of $\mathrm{NO}_{2}^{-}$in the amount of $146 \mathrm{mg} / \mathrm{L}$ and a decrease in $\mathrm{HNO}_{3}^{-}$by $200 \mathrm{mg} / \mathrm{L}$. Transient accumulation of nitrite intermediate was detected in the bottles due to a higher reduction rate of nitrate to nitrite, than nitrite to $\mathrm{NO}_{\text {(gas) }}$ or $\mathrm{N}_{2 \text { (gas) }}$ (Yi, et al., 2007). Sulfate sulfur did not change the concentration. Thermodynamic calculation has shown supersaturation of solution with respect to the minerals from Table 1 and chlorite (instead of kaolinite) and apatite $\mathrm{Ca}_{5}\left(\mathrm{PO}_{4}\right)_{3}(\mathrm{~F}, \mathrm{OH})$ additionally. The species of redox-dependent microcomponents have changed; they are $\mathrm{Fe}^{2+}, \mathrm{Cu}^{+}$, and $\mathrm{Mn}^{2+}$. The behavior of iron is determined by the redox buffer $\mathrm{Fe}^{2+} / \mathrm{FeOOH}_{(\mathrm{s})}$. The main species $\mathrm{UO}_{2}\left(\mathrm{CO}_{3}\right)_{2}^{2-}$ and $\mathrm{UO}_{2}\left(\mathrm{CO}_{3}\right)_{3}^{4-}$ at $\mathrm{pH} 6.9$ accounted for $70 \%$ and $30 \%$, respectively in equilibrium with $\beta-\mathrm{UO}_{2.25(\mathrm{~s})}$. Uranium concentration was $0.8 \mathrm{mg} / \mathrm{L}$ instead of initial $4 \mathrm{mg} / \mathrm{L}$.

Fundamental changes in the composition of solutions and solid phases occur on day 13 (Figure 1, point 13 days). In the solution a decrease in $\mathrm{HNO}_{3}^{-}$up to $5 \mathrm{mg} / \mathrm{L}$ and $\mathrm{NO}_{2}^{-}$up to $0.1 \mathrm{mg} / \mathrm{L}$ occurs, sulfate sulfur concentration decreases only slightly (by $300 \mathrm{mg} / \mathrm{L}$ ). In the model solid phase, sulfides (pyrite, chalcopyrite, and sphalerite) predominate; the main sulfur species is the hydrosulfide ion (Table 2). At Eh $-397 \mathrm{mV}$, the methanogenesis proceeds and there is no calcite in the model association.

$$
\mathrm{HCO}_{3}^{-}+4 \mathrm{H}_{2 \text { (gas) }}+\mathrm{H}^{+}=\mathrm{CH}_{4(\text { gas })}+3 \mathrm{H}_{2} \mathrm{O}
$$

Theoretically, the widely known annamox process can take place in aquifers (8). This anammox process involves the oxidation of ammonium to nitrogen gas using nitrite as an electron acceptor under anoxic condition (Wang et al., 2016).

$$
\mathrm{NH}_{4}^{+}+\mathrm{NO}_{2}^{-}=\mathrm{N}_{2(\text { gas })}+2 \mathrm{H}_{2} \mathrm{O}
$$

Table 2. Calculated model solid phases from the solution at Eh-397 mV, pH 7.1 and main species in this reduced solution on $13^{\text {th }}$ day of experiment.

\begin{tabular}{ccccccc}
\hline Mineral & Pyrite & Sphalerite & Chalcopyrite & Apatite & Chlorite & Uraninite $\mathrm{UO}_{2}$ \\
\hline mol/L & $1.42 \mathrm{E}-04$ & $4.62 \mathrm{E}-06$ & $4.92 \mathrm{E}-05$ & $6.84 \mathrm{E}-06$ & $5.31 \mathrm{E}-06$ & $1.68 \mathrm{E}-05$ \\
Species & $\mathrm{NH}_{4}^{+}$ & $\mathrm{H}_{2} \mathrm{~S}$ & $\mathrm{HS}^{-}$ & $\mathrm{Cu}(\mathrm{HS})_{2}^{-}$ & $\mathrm{CH}_{4}^{0}$ & $U(\mathrm{OH})_{4}^{0}$ \\
$\mathrm{~mol} / \mathrm{L}$ & $1.76 \mathrm{E}-05$ & $6.63 \mathrm{E}-03$ & $1.14 \mathrm{E}-02$ & $1.14 \mathrm{E}-06$ & $2.64 \mathrm{E}-03$ & $1.41 \mathrm{E}-14$ \\
\hline
\end{tabular}


According to [Carpenter et al., 2015] iron sulfide precipitates formed under sulfate reducing conditions may buffer U (IV) insoluble solid phases from reoxidation after oxidants re-enter the reducing zone. After 28 days there are no significant changes (Figure 1, point 28 days).

Finally, on the $64^{\text {th }}$ day, a sharp drop in the content of sulfate sulfur to 19.2 $\mathrm{mg} / \mathrm{L}$ was recorded. Thus, sulfate reduction lagged behind nitrate reduction by approximately 50 days. It seems to agree with the results reported by (Carpenter, et al., 2015). The measured concentration of $\mathrm{H}_{2} \mathrm{~S}_{\text {tot }}$ was $1200 \mathrm{mg} / \mathrm{L}$. This could be consumed by the formation of solid sulfides in the experimental bottles, but the initial content of heavy metals has been low enough, g/L-10.7 Fe, 3.2 Cu and $0.31 \mathrm{Zn}$. This result cannot be obtained with the help of equilibrium thermodynamic modeling. The reason is that Eh, as can be seen in Figure 1, remained constant during the three last sampling. An intelligible explanation can be found in (Yi, et al., 2007) (Londry, et al., 1999): nitrate removal at the early stage is due to denitrifying bacteria, as nitrate can stimulate their growth. Sulfate reducing bacteria (SRB) were unlikely to be responsible for nitrate elimination and nitrate is a strong inhibitor of SRB activity. From the thermodynamic point of view, one could compare the $\mathrm{f}_{\mathrm{O} 2}$ partial fugacity in the reactions:

$$
\begin{gathered}
2 \mathrm{NO}_{3}^{-}+2 \mathrm{H}^{+}=\mathrm{N}_{2(\text { gas })}+2.5 \mathrm{O}_{2}+\mathrm{H}_{2} \mathrm{O}=\operatorname{lgf} \mathrm{O}_{2}-4.5 \\
\mathrm{SO}_{4}{ }^{2-}+\mathrm{H}^{+}=\mathrm{HS}^{-}+2 \mathrm{O}_{2} \operatorname{lgf} \mathrm{O}_{2}-69.8 \\
\left(\mathrm{UO}_{2}\right)\left(\mathrm{CO}_{3}\right)_{2}^{2-}+\mathrm{H}_{2} \mathrm{O}=\mathrm{UO}_{2(\mathrm{~s})}+\mathrm{O}_{2}+2\left(\mathrm{HCO}_{3}\right)^{-} \operatorname{lgf} \mathrm{O}_{2}-47.8
\end{gathered}
$$

Obviously, denitrification and sulfate reduction occur in completely different redox conditions and, with a gradual decrease in Eh, follow one after another with uranium reduction between them.

\section{Discussion}

Conventional nitrification-denitrification processes may be difficult and costly to apply to wastewaters with high nitrate and low carbon concentrations. The studied process of stimulated biological treatment may provide an efficient method of relatively fast nitrogen removal from wastewaters and prolonged sulfate reduction. The sharp increase in denitrification process was observed after the 13 days during our experiment. This is in agreement with previous studies and can be attributed to stimulation of denitrifiers by the injection of nutrient serum. Several other investigations have shown increasing microbial activity after bio-stimulation of aquifer sediments by the injection of electron donors into monitoring wells (Eschenbach et al., 2015).

Microbial reduction of soluble uranyl U (VI) to insoluble $\mathrm{UO}_{2(s)}$ is a promising remediation strategy for uranium-contaminated groundwater. Model calculations have shown: 1) initial solution equilibrium with $\mathrm{U}_{3} \mathrm{O}_{8(\mathrm{~s})}$ (Table 1), 2) precipitation of $\beta-\mathrm{UO}_{2.25(\mathrm{~s})}$ after the fall of Eh to $+115 \mathrm{mV}$ (of $3.2 \mathrm{mg}$ as $\mathrm{U}$ ), 3) precipitation of $\mathrm{UO}_{2(\mathrm{~s})}$ after the fall of Eh to $-397 \mathrm{mV}$ (Table 2). It is important to note that more detailed calculations have shown the appearance of $\mathrm{UO}_{2(\mathrm{~s})}$ in a 
solid phase at $-105 \mathrm{mV}$. Effects of environmental factors, including $\mathrm{pH}$ and coexisting ions on $\mathrm{U}(\mathrm{VI})$ bioreduction processes (UBP) was discussed in (Yi et al., 2007). It turned out that the bioprecipitation is depended strongly on $\mathrm{pH}$, increasing from $12.9 \%$ to $99.4 \%$ at $\mathrm{pH} 2.0$ and 6.0, respectively. Sulfate concentration $<4000 \mathrm{mgl} / \mathrm{L}$ did not affect UBP, at $20 \mathrm{mg} / \mathrm{L} \mathrm{Zn}$ or $10 \mathrm{mgl} / \mathrm{L} \mathrm{Cu}$, no UBP inhibition was observed and uraninite was detected in metal sulfide precipitate. No uraninite could be detected before nitrate removal, suggesting nitrate strongly inhibited UBP. It was also shown earlier (Abdelouas et al., 1998) that the species $\mathrm{UO}_{2}\left(\mathrm{CO}_{3}\right)_{2}^{2-}$ and $\mathrm{UO}_{2}\left(\mathrm{CO}_{3}\right)_{3}^{4-}$ at $\mathrm{pH} 7.0$ may be difficult to reduce by sulfide directly and require enzymatic reduction via electron transfer pathway.

In order to verify the applicability of model calculations, the X-ray fluorescence analysis (XRF) of solid phases after the experiments has been done (Table 3 ).

The light color of the first solid phase is due to the apatite $\mathrm{Ca}_{5}\left(\mathrm{PO}_{4}\right)_{3}(\mathrm{OH}, \mathrm{Cl})$ precipitation; uranium precipitation is confirmed in an amount of $4.5 \%$ (according to calculations as non-stoichiometric hydroxide), traces of sulfur are due to the micro-quantities of gypsum. The dark phase is enriched in iron and sulfur due to the precipitation of sulfide minerals; it is depleted in uranium (according to calculations as $\left.\mathrm{UO}_{2(\mathrm{~s})}\right)$. Future study should evaluate the reactivity and stability of this new $U$ (IV) phase in field-relevant sediment columns subjected to redox change.

During the redox experiments, we assessed the relative time of different contaminant sequestration by bio-stimulation. An attempt to accurately reproduce the experimental conditions in the thermodynamic model failed in some details. Measured $\mathrm{Eh}+190 \mathrm{mV}$ is low despite the high amount of nitrates, but according to calculations, $\mathrm{NH}_{4}^{+}$predominates in this solution. Slow kinetic of $\mathrm{SO}_{4}^{2-}$ reduction despite the sharply negative potential on the $13^{\text {th }}$ day of the experiment means electrochemical disequilibrium in experimental solution. According to the XRF-analysis and thermodynamic calculations, more than half of the uranium is deposited in the first stage as $\mathrm{UO}_{2+\mathrm{x}}$ oxides, and the rest, together with the sulfides in the reducing environment.

\section{Conclusions}

1) The removal of nitrates, sulfates and U(VI)reduction due to the stimulated microbiological activity was proved experimentally over extended time periods. Within 13 days after the start of serum injections, reducing conditions became

Table 3. Mean $(n=7)$ chemicalphasecompositionafter the serum addition ${ }^{\star}$ and after the end of experiment**.

\begin{tabular}{cccccccccccccccc}
\hline Phase,\% & $\mathrm{O}$ & $\mathrm{Na}$ & $\mathrm{Mg}$ & $\mathrm{Al}$ & $\mathrm{Si}$ & $\mathrm{P}$ & $\mathrm{S}$ & $\mathrm{Cl}$ & $\mathrm{K}$ & $\mathrm{Ca}$ & $\mathrm{Ti}$ & $\mathrm{Fe}$ & $\mathrm{Ni}$ & $\mathrm{Zn}$ & $\mathrm{U}$ \\
\hline The light phase $^{*}$ & 38.9 & 11.0 & 0.90 & 0.4 & 1.7 & 10.6 & 2.1 & 12.2 & 4.8 & 11.9 & 0 & 1 & 0 & 0 & 4.5 \\
The dark phase $^{* *}$ & 33.0 & 11.1 & 0.92 & 2.6 & 6.61 & 5.69 & 6.48 & 11.8 & 7.1 & 2.81 & 0.31 & 8.61 & 0.05 & 0.1 & 2.75 \\
\hline
\end{tabular}


more pronounced, as indicated by the sharp decrease in Eh and nitrate concentrations. Sulfate reduction was established approximately 50 days later, as additionally indicated by the increase in sulfide concentrations.

2) The thermodynamic model of the immobilization process of contaminants during the redox processes was carried out with the characteristics of the U, N, $\mathrm{S}$, and Fe species in solutions and solid phases. The developed model can be used as a starting point of assessment of the behavior of a group of redox sensitive elements in the process of bioremediation and additional kinetic constants from the literature will be used on the next step.

3) The use of denitrifying microorganisms to remediate $\mathrm{NO}_{x}^{-}$-contaminated waters may be a solution for its removal in technogenic environments. The sulphate and chloride contamination of aquifers groundwater remains underestimated.

\section{Acknowledgements}

This study was supported by the Russian Foundation for Basic Research (grant \# 17-05-00707) and State assignments No. 0330-2016-0010 (IGM SB RAS).

\section{Conflicts of Interest}

The authors declare no conflicts of interest regarding the publication of this paper.

\section{References}

Abdelouas, A., Lutze, W., \& Nuttall, H. E. (1998). Chemical Reduction of Uranium in Groundwater at a Mill Tailings Site. Journal of Contaminant Hydrology, 34, 343-361.

Boguslavskii, A. E., Gas'kova, O. L., \& Shemelina, O. V. (2016). Geochemical Model of the Environmental Impact of Low-Level Radioactive Sludge Repositories in the Course of Their Decommissioning. Radiochemistry, 58, 323-328. https://doi.org/10.1134/S1066362216030164

Carpenter, J., Bi Y., \& Hayes, K. F. (2015). Influence of Iron Sulfides on Abiotic Oxidation of $\mathrm{UO}_{2}$ by Nitrite and Dissolved Oxygen in Natural Sediments. Environmental Science \& Technology, 49, 1078-1085. https://pubs.acs.org/doi/10.1021/es504481n

Coby, A. J., \& Picardal, F. W. (2005). Inhibition of $\mathrm{NO}_{3}^{-}$and $\mathrm{NO}_{2}^{-}$Reduction by Microbial Fe(III) Reduction: Evidence of a Reaction between $\mathrm{NO}_{2}^{-}$and Cell Surface-Bound $\mathrm{Fe}^{2+}$. Applied and Environmental Microbiology, 71, 5267-5274. http://aem.asm.org/content/71/9/5267.full https://doi.org/10.1128/AEM.71.9.5267-5274.2005

Eschenbach, W., Well, R., \& Walther, W. (2015). Predicting the Denitrification Capacity of Sandy Aquifers from in Situ Measurements Using Push-Pull ${ }^{15} \mathrm{~N}$ Tracer Tests. Biogeosciences, 12, 2327-2346. https://doi.org/10.5194/bg-12-2327-2015

Gaskova, O. L., Boguslavsky, A. E., \& Shemelina, O. V. (2015). Uranium Release from Contaminated Sludge Materials and Uptake by Subsurface Sediments: Experimental Study and Thermodynamic Modeling. Applied Geochemistry, 55, 152-159. https://doi.org/10.1016/j.apgeochem.2014.12.018

Gaskova, O. L., Strakhovenko, V. D., Ermolaeva, N. I., Zarubina, E. Yu., \& Ovdina, E. A. 
(2017). A Simple Method to Model the Reduced Environment of Lake Bottom Sapropel Formation. Chinese Journal of Oceanology and Limnology (CJOL), 35, 956-966. https://doi.org/10.1007/s00343-017-5345-9

Hallbeck, L., \& Pedersen, K. (2012). Culture-Dependent Comparison of Microbial Diversity in Deep Granitic Groundwater from Two Sites Considered for a Swedish Final Repository of Spent Nuclear Fuel. FEMS Microbiology Ecology, 81, 66-77. https://doi.org/10.1111/j.1574-6941.2011.01281.x

Keith-Roach, M. J., \& Livens, F. R. (2002). Interactions of Microorganisms with Radionuclides. Elservier, Amsterdam, New York, 408 p. https://trove.nla.gov.au/version/44951714

Londry, K. L., \& Suflita, J. M. (1999). Use of Nitrate to Control Sulfide Generation by Sulfate-Reducing Bacteria Associated with Oily Waste. Journal of Industrial Microbiology and Biotechnology, 22, 582-589. https://doi.org/10.1038/sj.jim.2900668

Nordstrom, D. K. (2000). Aqueous Redox Chemistry and the Behavior of Iron in Acid Mine Waters (естьвпапкеСанья). https://water.usgs.gov/nrp/proj.bib/Publications/2002/nordstrom_epa.pdf

Safonov, A. V., Boguslavskii, A. E., Boldyrev, K. A., \& Zayceva, L. V. (2019). Biogenic Factors of Geochemical Uranium Anomalies Formation in Subsurface Waters Near to Novosibirsk Chemical Concentrates Plant Slurry Storage. Geochemistry International, 57 , in press.

Shvarov, Yu. V. (2008). HCh: New Potentialities for the Thermodynamic Simulation of Geochemical Systems Offered by Windows. Geochemistry International, 46, 834-839.

Stucker, V. K., Kenneth, D. R., Williams, H., Sharp, J. O., \& Ranville, J. F. (2014). Thioarsenic Species Associated with Increased Arsenic Release during Biostimulated Subsurface Sulfate Reduction. Environmental Science \& Technology, 48, 13367-13375. https://doi.org/10.1021/es5035206

Wang, S., Radny, D., Huang, S., Zhuang, L., Zhao, S., Berg, M., Jetten, M. S. M., \& Zhu, G. (2016) Nitrogen Loss by Anaerobic Ammonium Oxidation in Unconfined Aquifer Soils. Scientific Reports, 7, 40173. https://doi.org/10.1038/srep40173

Yi, Z.-J., Tan, K.-X., Tan, A.-L., Yu, Z.-X., \& Wan, S-Q. (2007) Influence of Environmental Factors on Reductive Bioprecipitation of Uranium by Sulfate Reducing Bacteria. International Biodeterioration \& Biodegradation, 60, 258-266.

https://doi.org/10.1016/j.ibiod.2007.04.001 